\title{
Emerging Infection, Vaccination, and Guillain-Barré Syndrome: A Review
}

\author{
Haruki Koike (D) - Atsuro Chiba · Masahisa Katsuno
}

Received: May 4, 2021 / Accepted: May 28, 2021 / Published online: June 12, 2021

(c) The Author(s) 2021

\begin{abstract}
Guillain-Barré syndrome (GBS) is an autoimmune disorder of the peripheral nervous system that typically develops within 4 weeks after infection. In addition to conventional infectious diseases with which we are familiar, emerging infectious diseases, such as Zika virus infection and coronavirus disease 2019 (COVID-19) caused by severe acute respiratory syndrome coronavirus 2 (SARS-CoV-2), have also been suggested to be associated with GBS. GBS is mainly categorized into a demyelinating subtype known as acute inflammatory demyelinating polyneuropathy (AIDP) and an axonal subtype known as acute motor axonal neuropathy (AMAN). Most patients who develop GBS after Zika virus infection or COVID-19 have AIDP. The concept of molecular mimicry between pathogens and human peripheral nerve components was established through studies of AMAN with anti-ganglioside GM1 antibodies occurring after Campylobacter jejuni infection. Although such mimicry
\end{abstract}

H. Koike $(\bowtie) \cdot$ M. Katsuno

Department of Neurology, Nagoya University

Graduate School of Medicine, Nagoya 466-8550, Japan

e-mail: koike-haruki@med.nagoya-u.ac.jp

A. Chiba

Department of Neurology, Faculty of Medicine,

Kyorin University, Tokyo, Japan between specific pathogens and myelin or Schwann cell components has not been clearly demonstrated in AIDP, a similarity of Zika virus and SARS-CoV-2 proteins to human proteins has been suggested. With the development of global commerce and travel, emerging infectious diseases will continue to threaten public health. From this viewpoint, the development of vaccines and antiviral drugs is important to prepare for and control emerging infectious diseases. Although a decrease in the number of patients after the 2015-2016 Zika epidemic increased the difficulty in conducting phase 3 trials for Zika virus vaccines, the efficacy and safety of new vaccines have recently been demonstrated for COVID-19. In general, vaccines can decrease the risk of infectious disease by stimulating the immune system, and discussions regarding an increased risk of autoimmune disorders, such as GBS, have been ongoing for many years. However, the risk of GBS is not considered a legitimate reason to limit the administration of currently available vaccines, as only a trivial association or no association with GBS has been demonstrated.

Keywords: Adverse events; Clinical trials; Epidemiology; Glycolipids; Pathogenesis; Pathophysiology; Prevention; Treatment; Vaccine; World Health Organization 


\section{Key Summary Points}

Guillain-Barré syndrome (GBS) is an autoimmune disorder of the peripheral nervous system that typically develops following infection.

The association of emerging infectious diseases, such as Zika virus infection and coronavirus disease 2019 (COVID-19), with GBS is a topic of debate.

Some investigators have suggested that mechanisms resulting from molecular mimicry between viral proteins and human proteins participate in the pathogenesis of Zika/COVID-19associated GBS.

Although the development of vaccines is important to prepare for and control emerging infectious diseases, discussions regarding an increased risk of GBS have been ongoing for many years.

The incidence of infections contracted among unvaccinated people and the effectiveness of the vaccine in preventing infection should also be considered in the estimation of the overall risk-benefit ratio regarding the development of GBS following vaccination, because contracting an infection itself might also result in an increased risk of GBS development.

\section{DIGITAL FEATURES}

This article is published with digital features, including a summary slide, to facilitate understanding of the article. To view digital features for this article go to https://doi.org/10.6084/ m9.figshare.14696043.

\section{INTRODUCTION}

Guillain-Barré syndrome (GBS) is an autoimmune disorder of the peripheral nervous system that typically manifests as rapidly progressive ascending paralysis, with or without sensory and autonomic dysfunction, following an infection [1]. The incidence rate of this disease is 0.84 to $1.91 / 100,000$ per year according to studies performed in North America and Europe [2], whereas lower incidences of $0.42 / 100,000$ and $0.67 / 100,000$ per year have been reported in Japan and China, respectively [3, 4]. Seasonal variation in the incidence of GBS suggests that the occurrence of this disease is closely associated with the prevalence of infectious diseases, such as upper respiratory tract infections in winter and gastrointestinal tract infections in summer [5]. In addition to conventional infectious diseases with which we are familiar, emerging infectious diseases may also be associated with GBS. Since the establishment of the International Health Regulations Emergency Committee of the World Health Organization in 2005, six public health emergencies of international concern regarding emerging infectious diseases have been declared [6]. These include the swine influenza H1N1 strain pandemic in 2009, the resurgence of polio in 2014, the Ebola epidemic in West Africa in 2014 and in the Republic of the Congo in 2018-2019, the emergence of Zika virus in the Americas in 2015-2016, and the coronavirus disease 2019 (COVID-19) pandemic [6]. Among these, the association of Zika virus infection and COVID19 with GBS is a topic of debate [7].

In this review, we describe an association between GBS and newly emerging infectious diseases by focusing on Zika virus infection and COVID-19. Because massive vaccination campaigns against COVID-19 are ongoing in many countries, current knowledge about the development of GBS after vaccination is also summarized. This article is based on previously conducted studies and does not contain any studies with human participants or animals performed by any of the authors. 


\section{ANTECEDENT INFECTION AND GBS}

GBS usually develops within 4 weeks following the occurrence of antecedent events $[8,9]$. Bacterial or viral infection is the most common antecedent event; however, GBS has also been reported to occur after vaccination, surgery, or the administration of immune checkpoint inhibitors [10]. Several pathogens, including Campylobacter jejuni, Mycoplasma pneumoniae, cytomegalovirus, Epstein-Barr virus, hepatitis A virus, influenza A virus, and influenza B virus, have been suggested to be associated with the development of GBS $[8,9]$. The production of autoantibodies directed against peripheral nerve components, particularly gangliosides, induced by infection with these pathogens is considered to play an important role in the pathogenesis of GBS [1].

GBS is categorized into a demyelinating subtype known as acute inflammatory demyelinating polyneuropathy (AIDP) and an axonal subtype known as acute motor axonal neuropathy (AMAN) or acute motor sensory axonal neuropathy (AMSAN) based on the absence or presence of sensory involvement [11]. Although antecedent infection has been reported for both the demyelinating and axonal subtypes, some pathogens are closely associated with a specific form [4, 12]. For example, GBS that occurs after Zika virus infection or COVID19 usually manifests as AIDP, as described later, whereas Campylobacter jejuni is strongly associated with AMAN [12].

The concept of molecular mimicry between pathogens and human peripheral nerve components was established through studies of AMAN in which anti-ganglioside GM1 antibodies developed after Campylobacter jejuni infection (Fig. 1) [1]. Specifically, immunoglobulin G (IgG) antibodies against lipooligosaccharides located in the outer membrane of Campylobacter jejuni, which are produced as a result of infection, also react to host ganglioside GM1 localized to the axolemma of motor fibers [1]. A previous study demonstrated deposition of IgG and complement proteins on the axolemma of motor fibers in patients with AMAN, which supports this view [13]. Hence, membrane attack complexes formed by activation of complement cascades resulting from the attachment of autoantibodies cause axonal damage in AMAN $[1,11]$.

The hypothesis of molecular mimicry has not been clearly demonstrated in AIDP [12]. Although phagocytosis of myelin by macrophages has been recognized to be important in AIDP, the mechanisms that drive macrophages to initiate myelin phagocytosis have not been clarified [14]. However, antecedent infection and deposition of complement proteins in biopsied or autopsied peripheral nerve specimens suggest that mechanisms similar to those in AMAN also participate in AIDP $[14,15]$.

\section{ZIKA VIRUS AND GBS}

\section{Zika Virus Infection}

Zika virus is a type of arthropod-borne virus called an arbovirus. It is composed of a singlestranded, positive-sense enveloped RNA virus of the genus Flavivirus from the family Flaviviridae, which includes West Nile, yellow fever, dengue, and the Japanese encephalitis viruses [16]. This virus is transmitted to humans by mosquitoes such as Aedes aegypti, Aedes africanus, Aedes albopictus, and Aedes luteocephalus [17, 18]. Human-to-human transmission occurs through sexual contact [19], blood transfusion [20], or organ transplantation [21]. Transmission from mother to fetus also occurs and leads to the occurrence of microcephaly in newborns [22]. Although most individuals infected with Zika virus are asymptomatic, approximately 20\% experience symptoms such as fever, headache, posterior orbital pain, conjunctival hyperemia, rash, arthralgia, or myalgia after the 2- to 7-day incubation period $[18,23]$.

This virus was discovered in a rhesus monkey in the Zika forest of Uganda in 1947 [16]. Since then, human cases had been only sporadically reported in Africa and Southeast Asia until the first outbreak on Yap Island in the Federated States of Micronesia in 2007 [17]. Next, a large outbreak occurred in French Polynesia from 2013 to 2014 and subsequently spread to other 


\section{Production of antibodies to surface epitopes}
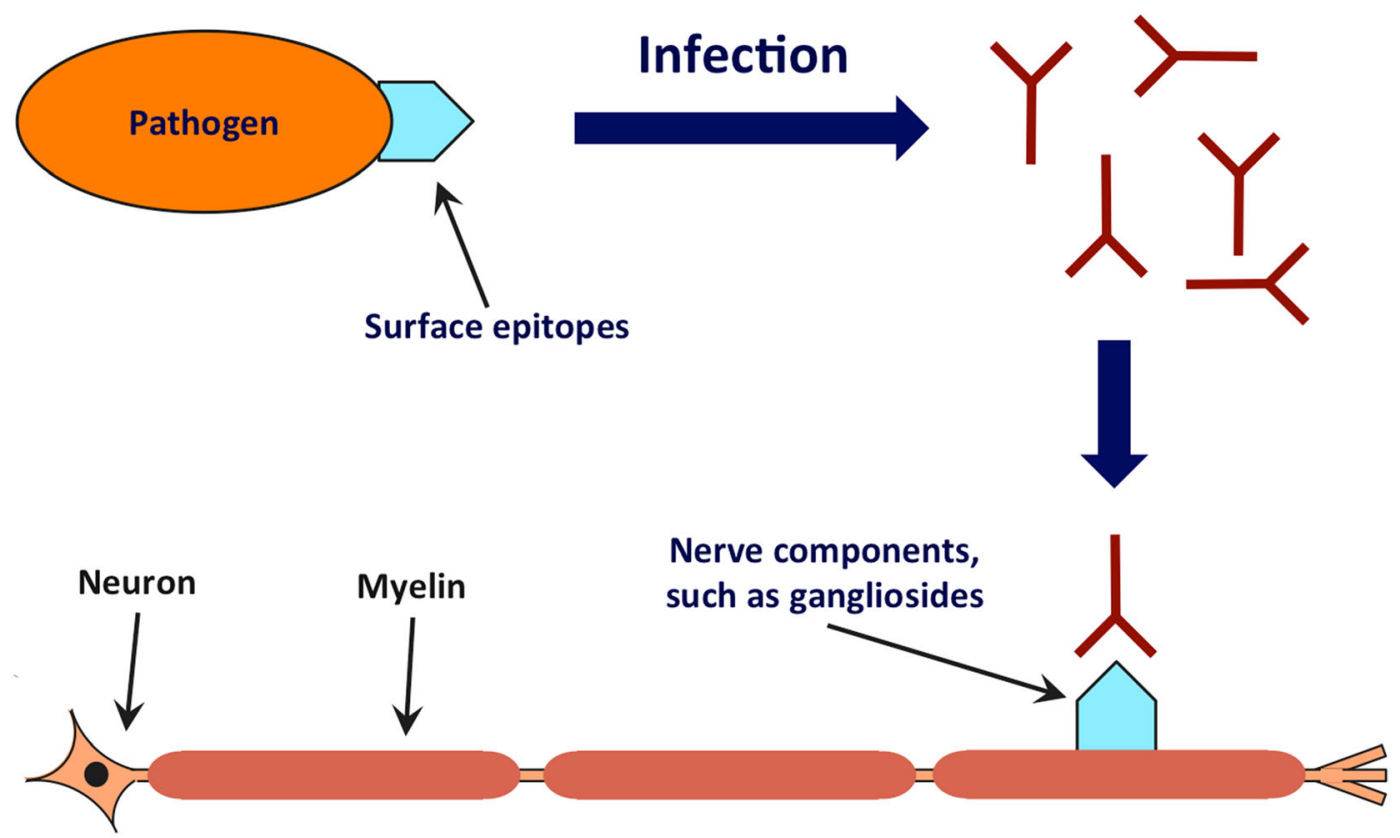

Fig. 1 The concept of molecular mimicry between pathogens and human peripheral nerve components. Auto antibodies against surface epitopes of pathogens produced as a result of infection also react to host peripheral nerve components

Pacific islands, including New Caledonia, Easter Island, Cook Islands, and Samoa [18]. In 2015, an outbreak occurred in northeastern Brazil and spread to North America, lasting until the end of 2016 [24].

\section{Association Between Zika Virus Infection and GBS}

Although Zika virus infection was considered self-limited until the epidemic on Yap Island, an unusual increase in the incidence of acquired neurological disorders, particularly GBS, was noted after the 2013 outbreak in French Polynesia [25]. The first reported patient with GBS associated with Zika virus infection was a French Polynesian woman who developed GBS 7 days after experiencing influenza-like symptoms in November 2013 [26]. Although Zika virus was not detected using reverse transcription polymerase chain reaction (RT-PCR) in a blood sample obtained 8 days after the onset of influenza-like symptoms (corresponding to
1 day after the onset of GBS), serum IgM specific for Zika virus was positive on enzyme-linked immunosorbent assay (ELISA) [26]. According to a single-center study, 42 patients were diagnosed with GBS between October 2013 and April 2014 during the outbreak in French Polynesia [25]. Of these patients, 39 had IgM antibodies against Zika virus and 37 reported antecedent symptoms compatible with Zika virus infection [25]. Considering the number of inhabitants in French Polynesia, up to a 20-fold increase in the incidence of GBS was suggested in this area during the outbreak [27].

Subsequently, an increased incidence of GBS was reported in Latin American and Caribbean countries that paralleled the spread of Zika virus infection [28-30]. Compared with that of the pre-Zika era, the incidence of GBS increased 2.7 times in Bahia state, Brazil; 3.1 times in Colombia; 2.5 times in the Dominican Republic; 2.0 times in El Salvador; 2.4 times in Honduras; 5.0 times in Suriname; and 9.8 times in Venezuela [28]. 


\section{Clinical Characteristics and Therapeutic Response of GBS Associated with Zika Virus Infection}

An important point of the characteristics of GBS associated with Zika virus infection is that patients usually show electrophysiological findings compatible with AIDP, such as a slowing of conduction velocities and prolongation of distal motor latencies [31]. According to large-scale studies of GBS performed during the Zika virus outbreak, the median duration from the onset of antecedent infection to that of GBS ranged from 6 to 10 days [25, 29, 30]. Clinical features are characterized by weakness predominantly in the lower limbs and frequent involvement of the cranial nerves, particularly the facial nerves $[25,29,30]$. As in patients with AIDP unrelated to Zika virus infection, sensory and autonomic disturbances have also been reported $[25,29,30]$. The progression tends to be rapid, and respiratory muscle paralysis frequently occurs, which necessitates care in an intensive care unit (ICU) [32]. As in patients with classical GBS, an increase in cerebrospinal fluid protein without elevated cell counts is observed in most patients with Zika-associated GBS $[25,29]$.

Intravenous immunoglobulin and plasma exchange have been established as effective treatments not only for classical GBS but also for GBS associated with Zika virus infection $[25,30,32]$. The prognosis seems to be similar for both classical GBS and Zika-associated GBS [33].

\section{Immunopathogenesis of GBS Associated with Zika Virus Infection}

As described earlier, anti-ganglioside antibodies are deeply involved in the pathogenesis of GBS [1]. A recent animal study demonstrated the production of IgG antibodies reactive to gangliosides, such as GD1a and GD1b, during Zika virus infection [34]. Another study showed increased levels of anti-ganglioside GD3 antibodies in sera obtained from patients infected with Zika virus with no neurological symptoms [35]. These findings suggest that molecular mimicry of gangliosides is involved in the pathogenesis of GBS that develops after Zika virus infection, which is similar to GBS that occurs after Campylobacter jejuni infection. To support this view, a study examining IgM and IgG antibodies against multiple glycolipids, including gangliosides, using a high-throughput ELISA approach revealed that patients with GBS associated with Zika virus infection tend to present higher levels of anti-ganglioside antibodies compared with patients with Zika virus infection alone [36]. The first large-scale study of GBS associated with Zika virus infection performed in French Polynesia from 2013 to 2014 demonstrated the presence of serum antibodies against glycolipids, including gangliosides, in 13 of 42 patients [25].

However, anti-ganglioside antibodies are typically associated with AMAN but not with AIDP $[12,14]$. As most patients with Zika virusassociated GBS have AIDP [31], the significance of anti-ganglioside antibodies should be interpreted with caution. Actually, an extensive investigation of anti-glycolipid antibodies, including anti-ganglioside antibodies, revealed no specific antibody signature in sera obtained from patients with GBS during the outbreak of Zika virus infection in northeast Brazil [37]. Nevertheless, mimicry between Zika virus polyproteins and human GBS-related proteins was reported [38], which suggests that peripheral nervous system components other than glycolipids/gangliosides could also be the target of autoantibodies in GBS associated with Zika virus infection.

In addition to such autoantibody production attributable to molecular mimicry, some investigators have considered direct invasion of the peripheral nervous system by Zika virus to be the mechanism responsible for GBS associated with Zika virus infection [33]. A recent study demonstrated that Zika virus could infect both neurons and Schwann cells [39]. As Schwann cells form the myelin sheath, a direct infection of Schwann cells with Zika virus may explain the predominance of AIDP rather than AMAN. Patients with concurrent onset of Zika virus infection and GBS or those in whom Zika virus was detected in the serum in parallel with the 
progression of GBS symptoms have been reported [40, 41], which supports this view.

\section{SARS-COV-2 AND GBS}

\section{COVID-19}

COVID-19 is an infectious disease caused by the novel severe acute respiratory syndrome (SARS) coronavirus (SARS-CoV) 2 (SARS-CoV-2). SARSCoV-2 is also a single-stranded, positive-sense enveloped RNA virus of the genus Betacoronavirus in the family Coronaviridae, which includes SARS-CoV and Middle East respiratory syndrome coronavirus (MERS-CoV) [42]. Although coronaviruses are known to cause common cold symptoms, three new coronaviruses caused outbreaks of severe disease in the 2000s. The first was SARS-CoV, which originated in Guangdong province in China and caused an epidemic of SARS from 2002 to 2003 [43]. SARS was revealed to be a zoonotic disease, as similar viruses were isolated from caged wild animals, such as palm civets and raccoon dogs, which were sold for consumption in Guangdong province during the outbreak [44]. The second was MERS-CoV, which was first isolated from a patient with pneumonia and renal failure in Saudi Arabia in 2012 [45]. Dromedary camels are considered reservoirs of MERS-CoV [46]. SARS-CoV-2, which is the third coronavirus disease, was first detected in the city of Wuhan in Hubei province of China in December 2019, after which it rapidly spread worldwide [47]. Although bats and pangolins were initially suspected to have infected humans with this virus, the animal origin of SARS-CoV-2 remains unclear [42].

SARS-CoV-2 is transmitted from person to person primarily via respiratory droplets resulting from coughing, sneezing, or shouting during face-to-face exposure or via surface contamination [48]. SARS-CoV-2 infection may be asymptomatic, or it may cause a wide spectrum of symptoms that range from mild symptoms involving the upper respiratory tract to life-threatening multi-organ failure, particularly acute respiratory distress syndrome [49]. According to a study that identified presymptomatic individuals at their time of departure from Wuhan and followed them until the development of symptoms during the first COVID-19 outbreak, the median incubation period was 7.8 days, and the incubation period was longer than 14 days in $5-10 \%$ of patients [50].

\section{Association Between COVID-19 and GBS}

During this pandemic, variable neurological manifestations, such as stroke, olfactory-gustatory dysfunctions (i.e., anosmia and ageusia), encephalitis, myelitis, and GBS, have been suggested to be associated with SARS-CoV-2 infection [51]. The first reported patient with GBS associated with SARS-CoV-2 infection was a woman who had returned to Shanghai from Wuhan on January 19, 2020 [52]. This patient initially presented with acute weakness in both legs on January 23, and pneumonia was detected using computed tomography on January 30. RT-PCR of an oropharyngeal swab sample revealed SARS-CoV-2 [52]. A study of patients who were treated in the emergency departments in Spain during the peak pandemic period from March to April 2020 demonstrated that the frequency of GBS was higher among patients with COVID-19 than those without COVID-19 (0.15\% versus 0.02\%) [53]. Another study in northern Italy also suggested an increased incidence of GBS from March to April 2020 compared with that in the same months in 2019 (rate per year estimated to be 2.43/ $1,000,000$ and $0.93 / 1,000,000$ in 2020 and 2019, respectively) [54].

However, a causal relationship between GBS and SARS-CoV-2 infection is still controversial [51]. An important issue that should be considered is that severe lockdown measures due to the COVID-19 pandemic have decreased the incidence of conventional infectious diseases that may be related to GBS. For example, a study of patients with GBS using data obtained from the UK National Immunoglobulin Database demonstrated that the number of patients with GBS treated in UK hospitals decreased between March and May 2020 compared with that in the same months in 2016-2019 [55]. 


\section{Clinical Characteristics and Therapeutic Response of GBS Associated with COVID- 19}

As in GBS associated with Zika virus infection, the electrophysiological features of GBS associated with COVID-19 are usually characterized by findings suggestive of demyelination, which is compatible with AIDP [56-58]. However, patients considered to have AMAN or AMSAN have also been reported [54, 56, 58-60].

According to a systematic review of the literature from January to June 2020, the mean interval between the onset of COVID-19 and GBS symptoms in 36 patients was calculated to be 11.5 days [57]. However, symptoms of COVID-19 were not obvious in two other patients [57]. A study that assessed 30 patients with GBS associated with COVID-19 who were diagnosed at 12 referral hospitals in northern Italy reported a longer interval (24.2 days) [54]. In that study, GBS symptoms occurred after the resolution of COVID-19 symptoms in 5 patients, whereas GBS symptoms began when COVID-19 symptoms were still present in the remaining 25 [54]. That study also assessed 17 patients with GBS without COVID-19 who were diagnosed at the same hospitals and in the same months of the previous year. A comparison of clinical features revealed that patients with GBS with COVID-19 more frequently had AIDP, more severe weakness necessitating ICU admission, and hypotension compared with those without COVID-19 [54]. Findings in the cerebrospinal fluid were similar between the GBS groups with and without COVID-19 [54].

Intravenous immunoglobulin and plasma exchange have been used for the treatment of GBS with COVID-19 [54, 57]. Although the response to treatment seems to be similar between patients with GBS with and without COVID-19 in the short term [54], long-term outcomes have not yet been clarified. It should be noted that patients with COVID-19 tend to have complications of pneumonia and are more frequently intubated [55].

\section{Immunopathogenesis of GBS Associated with COVID-19}

It has been suggested that exacerbation of COVID-19 is triggered by an excessive host immune response induced by SARS-CoV-2 [48]. For example, the release of inflammatory signaling molecules, such as cytokines, from infected cells and leukocytes is considered important in the pathogenesis of acute respiratory distress syndrome resulting from SARSCoV-2 infection [48]. Some investigators have suggested that additional autoimmune mechanisms resulting from molecular mimicry between SARS-CoV-2 surface proteins and human proteins participate in the pathogenesis of complications associated with SARS-CoV-2 infection, such as acute respiratory distress syndrome [61], coagulopathy [62], and GBS [63].

Anti-ganglioside GD1b IgG antibodies have been reported in some patients who present with neurological syndromes associated with SARS-CoV-2 infection $[64,65]$. One of these patients exhibited symptoms of Miller Fisher syndrome, a variant of GBS characterized by acute ophthalmoplegia, gait ataxia, and areflexia [64]. As Miller Fisher syndrome is usually associated with anti-GQ1b antibodies [66], the significance of anti-GD1b antibodies is unclear. Nevertheless, anti-GD1b antibodies are closely associated with ataxia in patients with GBS [67]. Additionally, a previous study demonstrated the presence of anti-GD1b antibodies in some patients who concomitantly presented with symptoms of GBS and Miller Fisher syndrome [68]. Antibodies against GM1, GM2, GD1a, and GQ1b have also been reported in patients with GBS associated with COVID-19 [69, 70]. As described earlier, anti-ganglioside antibodies reported to be associated with GBS tend to be found in patients with AMAN rather than AIDP [12]. Further studies of antibodies are needed to verify the molecular mimicry hypothesis in GBS associated with SARS-CoV-2 infection.

It has been established that a SARS-CoV or SARS-CoV-2 infection occurs when the angiotensin-converting enzyme 2 (ACE2) protein in host cells binds to the receptor-binding domain of spike proteins on the surface of the virus [71]. 
Interestingly, it has been suggested that the spike proteins of SARS-CoV-2 also bind to sialic acids linked to host cell surface gangliosides, which may explain the increased transmissibility of SARS-CoV-2 compared with that of SARSCoV [72]. This affinity of spike proteins for gangliosides suggests that SARS-CoV-2 affects the nervous system directly. However, RT-PCR to detect SARS-CoV-2 in the cerebrospinal fluid is usually negative in patients with GBS associated with SARS-CoV-2 infection, which suggests that para-infectious mechanisms more likely participate as in classical GBS [73].

\section{VACCINATION AND GBS}

\section{New Vaccines for Emerging Infectious Diseases}

As in Zika virus infection and COVID-19, most emerging infectious diseases are vector-borne or zoonotic and are caused by viruses [74]. With the development of global commerce and travel, such diseases are considered to be a continued threat to public health. From this viewpoint, the development of vaccines and antiviral drugs is important to prepare for and control emerging infectious diseases. Currently, many researchers are dedicated to developing vaccines for SARS-CoV-2 to control the current pandemic [75]. The development of vaccines for Zika virus has also been undertaken because Zika virus infection not only causes GBS, but also causes microcephaly in newborns, which is a serious threat to pregnant women [22].

Inoculation with antigens composed of either live attenuated or inactivated forms of pathogens is the conventional strategy for vaccination, and new technical platforms using messenger RNA (mRNA), plasmid DNA, and viral vectors have also been developed [76]. No licensed vaccine is currently available for Zika virus [77], and no pre-existing basic or clinical findings related to Zika vaccines were available when the Zika virus outbreak occurred [74]. Additionally, a significant decrease in the number of patients with Zika virus infection after the 2015-2016 epidemic increased the difficulty in performing phase 3 trials even though vaccine candidates had passed phase 1 and 2 trials [78]. By contrast, experience from the efforts to develop vaccines for SARS-CoV and MERS-CoV was available for the development of SARS-CoV-2 vaccines [75]. On the basis of preclinical studies of vaccines for SARS-CoV and MERS-CoV, the antigenic target for vaccines was revealed to be the spike proteins on the surface of these coronaviruses, which are essential for transmission to host cells, as they bind to ACE2 and subsequently fuse with the membrane [71]. Therefore, most candidate vaccines for SARS-CoV- 2 have been designed to induce immune responses to spike proteins. Recently, the efficacy and safety of new COVID19 vaccines have been demonstrated, and these vaccines are currently available in many countries $[79,80]$.

\section{Association Between Vaccination and GBS}

Vaccination can decrease the risk of infection with certain diseases by stimulating the immune response to pathogens, and discussions regarding an increase in the risk of autoimmune disorders, such as GBS, have been ongoing for many years. For example, an occurrence of GBS has been reported in association with old types of rabies vaccines prepared from suckling mouse brain or mature sheep brain $[81,82]$. However, only a trivial association or no association has been found between GBS and currently available vaccines [83]. For example, a suggested association of the tetanus toxoid-containing vaccines and oral polio vaccine with GBS has now been discounted [84, 85]. Although concerns remain for measles/mumps/rubella, quadrivalent conjugate meningococcal, human papillomavirus, and influenza vaccines, the risk of GBS is not considered a legitimate reason to limit administration of these vaccines, because the benefits outweigh the risks [86].

As for new vaccines against COVID-19, no cases of GBS have been reported following vaccination in clinical trials of mRNA vaccines $[79,80]$. A clinical trial of a viral vector vaccine reported that two patients had developed GBS 10 days after inoculation [87, 88]. As one of these patients received a placebo, a causal 
relationship between vaccination and the development of GBS could not be established [88]. Recently, another patient in whom GBS developed 2 weeks after the first inoculation of a mRNA vaccine was reported [89]. Considering the growing number of individuals vaccinated for COVID-19 worldwide, such reports of GBS will increase in the near future. Even so, the causal relationship between COVID-19 vaccines and GBS development should be considered with caution, because GBS may develop by chance. In any case, the risk of GBS is not considered a legitimate reason to limit administration of currently available COVID-19 vaccines considering the efficacy of these vaccines in preventing COVID-19.

\section{Experience from Influenza Vaccination}

Regarding the association between vaccination and GBS, the influenza vaccine is probably the most extensively investigated. The first cluster of patients who developed GBS following influenza vaccination was noted during the National Influenza Immunization Program against an outbreak of swine influenza in 1976 [90]. This mass immunization program was stopped because of an increase as high as eightfold in the incidence of GBS (4.9-5.9 cases per million vaccine recipients) [91]. Since then, several attempts have been made to clarify the association between vaccination against seasonal influenza and GBS. However, these studies indicated very low or no risk of developing GBS in cases that received vaccines for subsequent seasonal influenza [92]. Even if an association exists, it is estimated to be approximately one additional case per million vaccinations [86].

It should be noted that contracting influenza itself might also result in an increased risk of GBS development even in the absence of vaccination [7]. According to a study using data obtained from healthcare databases covering approximately 13 million individuals in Ontario, Canada, between 1993 and 2011, the incidence of GBS within 6 weeks following influenza vaccination was $52 \%$ higher than that during the control interval of 9-42 weeks (relative incidence 1.52 ; 95\% CI 1.17-1.99) [93].
However, the relative incidence of GBS within 6 weeks following the development of an event coded as influenza was much higher than that after vaccination $(15.81$; 95\% CI 10.28-24.32) [93]. These findings indicate that in addition to the risk of GBS development following influenza vaccination, the incidence of contracting influenza among unvaccinated individuals and the effectiveness of the vaccine in preventing influenza should also be considered when estimating the overall risk of GBS development and the benefit of vaccination. Considering these factors, most seasonal influenza vaccines are considered useful in reducing the overall risk of GBS development if they are effective in reducing the incidence of influenza itself [86].

\section{SUMMARY AND CONCLUSIONS}

GBS is an autoimmune disorder of the peripheral nervous system that typically develops within 4 weeks following infection with various pathogens. In addition to conventional infectious diseases with which we are familiar, emerging infectious diseases such as Zika virus infection and COVID-19 caused by SARS-CoV-2 may also be associated with GBS [7]. An increased incidence of GBS was reported during outbreaks of Zika virus infection in French Polynesia from 2013 to 2014 and in Latin American and Caribbean countries from 2015 to $2016[25,28]$. By contrast, an association between COVID-19 and GBS is still controversial, as severe lockdown measures during the COVID-19 pandemic may have decreased the overall number of patients with GBS. This is probably due to a reduction in conventional infectious diseases that may be related to GBS [55]. Nevertheless, an increased incidence of GBS compared with that of the pre-COVID-19 era has been reported [53, 54].

GBS comprises a demyelinating subtype known as AIDP and an axonal subtype known as AMAN or AMSAN, and patients who develop GBS after Zika virus infection or COVID-19 usually have AIDP [12]. The concept of molecular mimicry between pathogens and human peripheral nerve components was established through studies of AMAN in which anti- 
ganglioside GM1 antibodies were observed after Campylobacter jejuni infection [1]. By contrast, such molecular mimicry between specific pathogens and myelin or Schwann cell components has not been clearly demonstrated in AIDP [12]. Nevertheless, similarities between Zika virus/SARS-CoV-2 proteins and human proteins have been suggested [38, 63]. A direct infection of neurons or Schwann cells by pathogens has also been suggested to be involved in the development of GBS, particularly in cases of Zika virus infection [39-41, 72].

With the development of global commerce and travel, emerging infectious diseases are considered a consistent public health threat. From this viewpoint, the development of vaccines and antiviral drugs is important to prepare for and control such emerging infectious diseases. Inoculation with antigens composed of either live attenuated or inactivated forms of pathogens is the conventional strategy for vaccination, and new technical platforms using mRNA, plasmid DNA, and viral vectors have also been developed [76]. Although a decrease in the number of patients after the 2015-2016 epidemic has increased the difficulty in conducting phase 3 trials for Zika virus vaccines [78], the efficacy and safety of new vaccines have been demonstrated for COVID-19 vaccines $[79,80]$. In general, vaccines can decrease the risk of infectious diseases by stimulating the immune system, and discussions regarding an increased risk of autoimmune disorders, such as GBS, have been ongoing for many years. However, the risk of GBS is not considered a legitimate reason to limit administration of currently available vaccines, because only a trivial association or no association has been found with GBS.

\section{ACKNOWLEDGEMENTS}

Funding. This work was supported in part by the Health and Labour Sciences Research Grant on Intractable Diseases (Neuroimmunological Diseases) from the Ministry of Health, Labour and Welfare of Japan (20FC1030). No funding or sponsorship was received for the publication of this article.

Authorship. All named authors meet the International Committee of Medical Journal Editors (ICMJE) criteria for authorship for this article, take responsibility for the integrity of the work as a whole, and have given their approval for this version to be published.

Authors' Contributions. Haruki Koike and Atsuro Chiba developed the concept of the article. Haruki Koike carried out the literature review. Haruki Koike wrote the first draft, and all authors critically evaluated the manuscript.

Disclosures. Haruki Koike is a member of the journal's Editorial Board. Atsuro Chiba and Masahisa Katsuno have nothing to disclose.

Compliance with Ethics Guidelines. This article is based on previously conducted studies and does not contain any studies with human participants or animals performed by any of the authors.

Data Availability. Data sharing is not applicable to this article as no datasets were generated or analyzed during the current study.

Open Access. This article is licensed under a Creative Commons Attribution-NonCommercial 4.0 International License, which permits any non-commercial use, sharing, adaptation, distribution and reproduction in any medium or format, as long as you give appropriate credit to the original author(s) and the source, provide a link to the Creative Commons licence, and indicate if changes were made. The images or other third party material in this article are included in the article's Creative Commons licence, unless indicated otherwise in a credit line to the material. If material is not included in the article's Creative Commons licence and your intended use is not permitted by statutory regulation or exceeds the permitted use, you will need to obtain permission directly from the copyright holder. To view a copy of this licence, 
visit http://creativecommons.org/licenses/bync/4.0/.

\section{REFERENCES}

1. Yuki N, Hartung HP. Guillain-Barré syndrome. N Engl J Med. 2012;366(24):2294-304.

2. McGrogan A, Madle GC, Seaman HE, de Vries CS. The epidemiology of Guillain-Barré syndrome worldwide. A systematic literature review. Neuroepidemiology. 2009;32(2):150-63.

3. Cheng Q, Wang DS, Jiang GX, Han H, Zhang Y, Wang WZ, Fredrikson S. Distinct pattern of agespecific incidence of Guillain-Barré syndrome in Harbin, China. J Neurol. 2002;249(1):25-32.

4. Matsui N, Nodera H, Kuzume D, Iwasa N, Unai Y, Sakai W, Miyazaki Y, Yamazaki H, Osaki Y, Mori A, Furukawa T, Tsukamoto-Miyashiro A, Shimatani Y, Yamasaki M, Izumi Y, Kusunoki S, Arisawa K, Kaji R. Guillain-Barré syndrome in a local area in Japan, 2006-2015: an epidemiological and clinical study of 108 patients. Eur J Neurol. 2018;25(5):718-24.

5. Webb AJ, Brain SA, Wood R, Rinaldi S, Turner MR. Seasonal variation in Guillain-Barré syndrome: a systematic review, meta-analysis and Oxfordshire cohort study. J Neurol Neurosurg Psychiatry. 2015;86(11):1196-201.

6. Jee Y. WHO International Health Regulations Emergency Committee for the COVID-19 outbreak. Epidemiol Health. 2020;42:e2020013.

7. Koike H, Katsuno, M. Emerging infectious diseases, vaccines, and Guillain-Barré syndrome. Clin Exp Neuroimmunol (in press).

8. Jacobs BC, Rothbarth PH, van der Meché FG, Herbrink P, Schmitz PI, de Klerk MA, van Doorn PA. The spectrum of antecedent infections in GuillainBarré syndrome: a case-control study. Neurology. 1998;51(4):1110-5.

9. Hao Y, Wang W, Jacobs BC, Qiao B, Chen M, Liu D, Feng X, Wang Y. Antecedent infections in GuillainBarré syndrome: a single-center, prospective study. Ann Clin Transl Neurol. 2019;6(12):2510-7.

10. Shahrizaila N, Lehmann HC, Kuwabara S. GuillainBarré syndrome. Lancet. 2021;397(10280):1214-28.

11. Koike $H$, Katsuno $M$. The role of macrophages in Guillain-Barré syndrome and chronic inflammatory demyelinating polyneuropathy. Neurol Clin Neurosci. 2021;9(3):203-10.
12. Koike H, Katsuno M. Macrophages and autoantibodies in demyelinating diseases. Cells. 2021;10(4): 844.

13. Hafer-Macko C, Hsieh ST, Li CY, Ho TW, Sheikh K, Cornblath DR, McKhann GM, Asbury AK, Griffin JW. Acute motor axonal neuropathy: an antibodymediated attack on axolemma. Ann Neurol. 1996;40(4):635-44.

14. Koike H, Fukami Y, Nishi R, Kawagashira Y, Iijima M, Katsuno M, Sobue G. Ultrastructural mechanisms of macrophage-induced demyelination in Guillain-Barré syndrome. J Neurol Neurosurg Psychiatry. 2020;91(6):650-9.

15. Hafer-Macko CE, Sheikh KA, Li CY, Ho TW, Cornblath DR, McKhann GM, Asbury AK, Griffin JW. Immune attack on the Schwann cell surface in acute inflammatory demyelinating polyneuropathy. Ann Neurol. 1996;39(5):625-35.

16. Weaver SC, Costa F, Garcia-Blanco MA, Ko AI, Ribeiro GS, Saade G, Shi PY, Vasilakis N. Zika virus: History, emergence, biology, and prospects for control. Antivir Res. 2016;130:69-80.

17. Duffy MR, Chen TH, Hancock WT, Powers AM, Kool JL, Lanciotti RS, Pretrick M, Marfel M, Holzbauer S, Dubray C, Guillaumot L, Griggs A, Bel M, Lambert AJ, Laven J, Kosoy O, Panella A, Biggerstaff BJ, Fischer M, Hayes EB. Zika virus outbreak on Yap Island, Federated States of Micronesia. N Engl J Med. 2009;360(24):2536-43.

18. Petersen LR, Jamieson DJ, Powers AM, Honein MA. Zika virus. N Engl J Med. 2016;374(16):1552-63.

19. Foy BD, Kobylinski KC, Chilson Foy JL, Blitvich BJ, da Rosa AT, Haddow AD, Lanciotti RS, Tesh RB. Probable non-vector-borne transmission of Zika virus, Colorado, USA. Emerg Infect Dis. 2011;17(5): 880-2.

20. Motta IJ, Spencer BR, da Silva SGC, Arruda MB, Dobbin JA, Gonzaga YB, Arcuri IP, Tavares RC, Atta EH, Fernandes RF, Costa DA, Ribeiro LJ, Limonte F, Higa LM, Voloch CM, Brindeiro RM, Tanuri A, Ferreira OC Jr. Evidence for transmission of zika virus by platelet transfusion. $\mathrm{N}$ Engl J Med. 2016;375(11):1101-3.

21. Nogueira ML, Estofolete CF, Terzian AC, do Vale EPM, da Silva RC, da Silva RF, Ramalho HJ, Charpiot IMF, Vasilakis N, Abbud-Filho M. Zika virus infection and solid organ transplantation: a new challenge. Am J Transplant. 2017;17(3):791-95.

22. Mlakar J, Korva M, Tul N, Popović M, Poljšak-Prijatelj M, Mraz J, Kolenc M, Resman Rus K, Vesnaver Vipotnik T, Fabjan Vodušek V, Vizjak A, Pižem J, 
Petrovec M, Avšič ŽT. Zika virus associated with microcephaly. N Engl J Med. 2016;374(10):951-8.

23. Kutsuna S. Zika virus infection: clinical overview with a summary of Japanese cases. Clin Exp Neuroimmunol. 2017;8(3):192-8.

24. Zhang Q, Sun K, Chinazzi M, Pastore Y, Piontti A, Dean NE, Rojas DP, Merler S, Mistry D, Poletti P, Rossi L, Bray M, Halloran ME, Longini IM Jr, Vespignani A. Spread of Zika virus in the Americas. Proc Natl Acad Sci USA. 2017;114(22):E4334-43.

25. Cao-Lormeau VM, Blake A, Mons $S$, Lastère $S$, Roche C, Vanhomwegen J, Dub T, Baudouin L, Teissier A, Larre P, Vial AL, Decam C, Choumet V, Halstead SK, Willison HJ, Musset L, Manuguerra JC, Despres P, Fournier E, Mallet HP, Musso D, Fontanet A, Neil J, Ghawché F. Guillain-Barré Syndrome outbreak associated with Zika virus infection in French Polynesia: a case-control study. Lancet. 2016;387(10027):1531-9.

26. Oehler E, Watrin L, Larre P, Leparc-Goffart I, Lastere S, Valour F, Baudouin L, Mallet H, Musso D, Ghawche F. Zika virus infection complicated by Guillain-Barre syndrome-case report, French Polynesia, December 2013. Euro Surveill. 2014;19(9):20720.

27. Musso D, Nilles EJ, Cao-Lormeau VM. Rapid spread of emerging Zika virus in the Pacific area. Clin Microbiol Infect. 2014;20(10):O595-6.

28. Dos Santos T, Rodriguez A, Almiron M, Sanhueza A, Ramon P, de Oliveira WK, Coelho GE, Badaró R, Cortez J, Ospina M, Pimentel R, Masis R, Hernandez F, Lara B, Montoya R, Jubithana B, Melchor A, Alvarez A, Aldighieri S, Dye C, Espinal MA. Zika virus and the Guillain-Barré syndrome-case series from seven countries. N Engl J Med. 2016;375(16): 1598-601.

29. Parra B, Lizarazo J, Jiménez-Arango JA, Zea-Vera AF, González-Manrique G, Vargas J, Angarita JA, Zuñiga G, Lopez-Gonzalez R, Beltran CL, Rizcala KH, Morales MT, Pacheco O, Ospina ML, Kumar A, Cornblath DR, Muñoz LS, Osorio L, Barreras P, Pardo CA. Guillain-Barré syndrome associated with zika virus infection in Colombia. N Engl J Med. 2016;375(16): 1513-23.

30. da Silva IRF, Frontera JA, de Filippis AMB, Nascimento OJMD, RIO-GBS-ZIKV Research Group. Neurologic complications associated with the zika virus in Brazilian adults. JAMA Neurol. 2017;74(10): 1190-8.

31. Uncini A, Shahrizaila N, Kuwabara S. Zika virus infection and Guillain-Barré syndrome: a review focused on clinical and electrophysiological subtypes. J Neurol Neurosurg Psychiatry. 2017;88(3):266-71.

32. Arias A, Torres-Tobar L, Hernández G, Paipilla D, Palacios E, Torres Y, Duran J, Ugarte US, ArdilaSierra A, Castellanos G. Guillain-Barré syndrome in patients with a recent history of Zika in Cúcuta, Colombia: a descriptive case series of 19 patients from December 2015 to March 2016. J Crit Care. 2017;37:19-23.

33. Nascimento OJM, da Silva IRF. Guillain-Barré syndrome and Zika virus outbreaks. Curr Opin Neurol. 2017;30(5):500-7.

34. Beaver JT, Mills LK, Swieboda D, Lelutiu N, Esser ES, Antao OQ, Scountzou E, Williams DT, Papaioannou N, Littauer EQ, Skountzou I. Zika virus-induced neuro-ocular pathology in immunocompetent mice correlates with anti-ganglioside autoantibodies. Hum Vaccin Immunother. 2020;16(9):2092-108.

35. Nico D, Conde L, Rivera-Correa JL, VasconcelosDos-Santos A, Mesentier-Louro L, Freire-de-Lima L, Arruda MB, Freire-de-Lima CG, Ferreira ODC Jr, Lopes Moreira ME, Zin AA, Vasconcelos ZFM, Otero RM, Palatnik-de-Sousa CB, Tanuri A, Todeschini AR, Savino W, Rodriguez A, Morrot A. Prevalence of IgG autoantibodies against GD3 ganglioside in acute zika virus infection. Front Med (Lausanne). 2018;9(5):25.

36. Rivera-Correa J, de Siqueira IC, Mota S, do Rosário MS, de Jesus PAA, Alcantara LCJ, Ernst JD, Rodriguez A. Anti-ganglioside antibodies in patients with Zika virus infection-associated Guillain-Barré Syndrome in Brazil. PLoS Negl Trop Dis. 2019;13(9): e0007695.

37. Leonhard SE, Halstead S, Lant SB, Militão de Albuquerque MFP, de Brito CAA, de Albuquerque LBB, Ellul MA, de Oliveira França RF, Gourlay D, Griffiths MJ, de Miranda Henriques-Souza AM, de Morais Machado MÍ, Medialdea-Carrera R, Mehta R, da Paz Melo R, Mesquita SD, Moreira ÁJP, Pena LJ, Santos ML, Turtle L, Solomon T, Willison HJ, Jacobs BC, Brito Ferreira ML. Guillain-Barré syndrome during the Zika virus outbreak in Northeast Brazil: an observational cohort study. J Neurol Sci. 2021;420: 117272.

38. Lucchese G, Kanduc D. Zika virus and autoimmunity: from microcephaly to Guillain-Barré syndrome, and beyond. Autoimmun Rev. 2016;15(8): 801-8.

39. Dhiman G, Abraham R, Griffin DE. Human Schwann cells are susceptible to infection with Zika and yellow fever viruses, but not dengue virus. Sci Rep. 2019;9(1):9951. 
40. Siu R, Bukhari W, Todd A, Gunn W, Huang QS, Timmings P. Acute Zika infection with concurrent onset of Guillain-Barré syndrome. Neurology. 2016;87(15):1623-4.

41. Gonzalez-Escobar G, Valadere AM, Adams R, Polson-Edwards K, Hinds AQJ, Misir A, Hospedales CJ. Prolonged Zika virus viremia in a patient with Guillain-Barré syndrome in Trinidad and Tobago. Rev Panam Salud Publica. 2018;41:e136.

42. $\mathrm{Hu}$ B, Guo H, Zhou P, Shi ZL. Characteristics of SARS-CoV-2 and COVID-19. Nat Rev Microbiol. 2021;19(3):141-54.

43. Zhong NS, Zheng BJ, Li YM, Poon LLM, Xie ZH, Chan KH, Li PH, Tan SY, Chang Q, Xie JP, Liu XQ, $\mathrm{Xu}$ J, Li DX, Yuen KY, Guan Y. Epidemiology and cause of severe acute respiratory syndrome (SARS) in Guangdong, People's Republic of China, in February, 2003. Lancet. 2003;362(9393):1353-8.

44. Guan Y, Zheng BJ, He YQ, Liu XL, Zhuang ZX, Cheung CL, Luo SW, Li PH, Zhang LJ, Guan YJ, Butt KM, Wong KL, Chan KW, Lim W, Shortridge KF, Yuen KY, Peiris JS, Poon LL. Isolation and characterization of viruses related to the SARS coronavirus from animals in southern China. Science. 2003;302(5643):276-8.

45. Zaki AM, van Boheemen S, Bestebroer TM, Osterhaus $\mathrm{AD}$, Fouchier RA. Isolation of a novel coronavirus from a man with pneumonia in Saudi Arabia. N Engl J Med. 2012;367(19):1814-20.

46. Sabir JS, Lam TT, Ahmed MM, Li L, Shen Y, Abo-Aba SE, Qureshi MI, Abu-Zeid M, Zhang Y, Khiyami MA, Alharbi NS, Hajrah NH, Sabir MJ, Mutwakil MH, Kabli SA, Alsulaimany FA, Obaid AY, Zhou B, Smith DK, Holmes EC, Zhu H, Guan Y. Co-circulation of three camel coronavirus species and recombination of MERS-CoVs in Saudi Arabia. Science. 2016;351(6268):81-4.

47. Chan JF, Yuan S, Kok KH, To KK, Chu H, Yang J, Xing F, Liu J, Yip CC, Poon RW, Tsoi HW, Lo SK, Chan KH, Poon VK, Chan WM, Ip JD, Cai JP, Cheng VC, Chen H, Hui CK, Yuen KY. A familial cluster of pneumonia associated with the 2019 novel coronavirus indicating person-to-person transmission: a study of a family cluster. Lancet. 2020;395(10223): 514-23.

48. Wiersinga WJ, Rhodes A, Cheng AC, Peacock SJ, Prescott HC. Pathophysiology, transmission, diagnosis, and treatment of coronavirus disease 2019 (COVID-19): a review. JAMA. 2020;324(8):782-93.

49. Huang C, Wang Y, Li X, Ren L, Zhao J, Hu Y, Zhang L, Fan G, Xu J, Gu X, Cheng Z, Yu T, Xia J, Wei Y, Wu W, Xie X, Yin W, Li H, Liu M, Xiao Y, Gao H, Guo L, Xie J, Wang G, Jiang R, Gao Z, Jin Q, Wang J,
Cao B. Clinical features of patients infected with 2019 novel coronavirus in Wuhan, China. Lancet. 2020;395(10223):497-506.

50. Qin J, You C, Lin Q, Hu T, Yu S, Zhou XH. Estimation of incubation period distribution of COVID-19 using disease onset forward time: a novel cross-sectional and forward follow-up study. Sci Adv. 2020;6(33):eabc1202.

51. Ellul MA, Benjamin L, Singh B, Lant S, Michael BD, Easton A, Kneen R, Defres S, Sejvar J, Solomon T. Neurological associations of COVID-19. Lancet Neurol. 2020;19(9):767-83.

52. Zhao H, Shen D, Zhou H, Liu J, Chen S. GuillainBarré syndrome associated with SARS-CoV-2 infection: causality or coincidence? Lancet Neurol. 2020;19(5):383-4. https://doi.org/10.1016/S14744422(20)30109-5.

53. Fragiel M, Miró Ò, Llorens $\mathrm{P}$, Jiménez S, Piñera $\mathrm{P}$, Burillo G, Martín A, Martín-Sánchez FJ, GarcíaLamberechts EJ, Jacob J, Alquézar-Arbé A, Juárez R, Jiménez B, Del Rio R, Mateo Roca M, García AH, López Laguna N, Lopez Diez MP, Pedraza García J, Fernández de Simón Almela A, Lopez Diaz JJ, Eiroa Hernández P, Ruiz de Lobera N, Porta-Etessam J, Fernández Pérez C, Calvo E, González Del Castillo J, SIESTA (Spanish Investigators in Emergency Situations Team) network. Incidence, clinical, risk factors and outcomes of Guillain-Barré in Covid-19. Ann Neurol. 2021;89(3):598-603.

54. Filosto M, Cotti Piccinelli S, Gazzina S, Foresti C, Frigeni B, Servalli MC, Sessa M, Cosentino G, Marchioni E, Ravaglia S, Briani C, Castellani F, Zara G, Bianchi F, Del Carro U, Fazio R, Filippi M, Magni E, Natalini G, Palmerini F, Perotti AM, Bellomo A, Osio M, Scopelliti G, Carpo M, Rasera A, Squintani G, Doneddu PE, Bertasi V, Cotelli MS, Bertolasi L, Fabrizi GM, Ferrari S, Ranieri F, Caprioli F, Grappa E, Broglio L, De Maria G, Leggio U, Poli L, Rasulo F, Latronico N, Nobile-Orazio E, Padovani A, Uncini A. Guillain-Barré syndrome and COVID-19: an observational multicentre study from two Italian hotspot regions. J Neurol Neurosurg Psychiatry (in press).

55. Keddie S, Pakpoor J, Mousele C, Pipis M, Machado PM, Foster M, Record CJ, Keh RYS, Fehmi J, Paterson RW, Bharambe V, Clayton LM, Allen C, Price O, Wall J, Kiss-Csenki A, Rathnasabapathi DP, Geraldes $\mathrm{R}$, Yermakova T, King-Robson J, Zosmer M, Rajakulendran S, Sumaria S, Farmer SF, Nortley R, Marshall CR, Newman EJ, Nirmalananthan N, Kumar G, Pinto AA, Holt J, Lavin TM, Brennan KM, Zandi MS, Jayaseelan DL, Pritchard J, Hadden RDM, Manji H, Willison HJ, Rinaldi S, Carr AS, Lunn MP. Epidemiological and cohort study finds no association between COVID-19 and Guillain-Barré syndrome. Brain. 2021;144(2):682-93. 
56. Caress JB, Castoro RJ, Simmons Z, Scelsa SN, Lewis RA, Ahlawat A, Narayanaswami P. COVID-19-associated Guillain-Barré syndrome: the early pandemic experience. Muscle Nerve. 2020;62(4):485-91.

57. Uncini A, Vallat JM, Jacobs BC. Guillain-Barré syndrome in SARS-CoV-2 infection: an instant systematic review of the first six months of pandemic. J Neurol Neurosurg Psychiatry. 2020;91(10): 1105-10.

58. Sriwastava S, Kataria S, Tandon M, Patel J, Patel R, Jowkar A, Daimee M, Bernitsas E, Jaiswal P, Lisak RP. Guillain Barré Syndrome and its variants as a manifestation of COVID-19: a systematic review of case reports and case series. J Neurol Sci. 2021;420: 117263.

59. Hirayama T, Hongo Y, Kaida K, Kano O. GuillainBarré syndrome after COVID-19 in Japan. BMJ Case Rep. 2020;13(10):e239218.

60. Petrelli C, Scendoni R, Paglioriti M, Logullo FO. Acute motor axonal neuropathy related to COVID19 infection: a new diagnostic overview. J Clin Neuromuscul Dis. 2020;22(2):120-1.

61. Angileri F, Legare S, Gammazza AM, de Macario EC, Macario AJL, Cappello F. Molecular mimicry may explain multi-organ damage in COVID-19. Autoimmun Rev. 2020;19(8):102591.

62. Morsy S, Morsy A. Epitope mimicry analysis of SARS-COV-2 surface proteins and human lung proteins. J Mol Graph Model. 2021;105:107836.

63. Lucchese G, Flöel A. SARS-CoV-2 and Guillain-Barré syndrome: molecular mimicry with human heat shock proteins as potential pathogenic mechanism. Cell Stress Chaperones. 2020;25(5):731-5.

64. Gutiérrez-Ortiz C, Méndez-Guerrero A, Rodrigo-Rey S, San Pedro-Murillo E, Bermejo-Guerrero L, GordoMañas R, de Aragón-Gómez F, Benito-León J. Miller Fisher syndrome and polyneuritis cranialis in COVID-19. Neurology. 2020;95(5):e601-5.

65. Guilmot A, Maldonado Slootjes S, Sellimi A, Bronchain M, Hanseeuw B, Belkhir L, Yombi JC, De Greef J, Pothen L, Yildiz H, Duprez T, Fillée C, Anantharajah A, Capes A, Hantson P, Jacquerye P, Raymackers JM, London F, El Sankari S, Ivanoiu A, Maggi P, van Pesch V. Immune-mediated neurological syndromes in SARS-CoV-2-infected patients. J Neurol. 2021;268(3):751-7.

66. Chiba A, Kusunoki S, Shimizu T, Kanazawa I. Serum IgG antibody to ganglioside GQ1b is a possible marker of Miller Fisher syndrome. Ann Neurol. 1992;31(6):677-9.
67. Kaida K, Kamakura K, Ogawa G, Ueda M, Motoyoshi K, Arita M, Kusunoki S. GD1b-specific antibody induces ataxia in Guillain-Barre syndrome. Neurology. 2008;71(3):196-201.

68. Taams NE, Notermans NC, Fokkink WR, Tio-Gillen AP, Huizinga R, Schreurs MWJ, Jacobs BC. Clinical relevance of serum antibodies to GD1b in immunemediated neuropathies. J Peripher Nerv Syst. 2018;23(4):227-34.

69. Dufour C, Co TK, Liu A. GM1 ganglioside antibody and COVID-19 related Guillain Barre Syndrome-a case report, systemic review and implication for vaccine development. Brain Behav Immun Health. 2021;12:100203.

70. Chan M, Han S, Kelly S, Tamimi M, Giglio B, Lewis A. A case series of Guillain-Barré Syndrome following Covid-19 infection in New York. Neurol Clin Pract. (in press).

71. Vaduganathan M, Vardeny O, Michel T, McMurray JJV, Pfeffer MA, Solomon SD. Renin-angiotensinaldosterone system inhibitors in patients with Covid-19. N Engl J Med. 2020;382(17):1653-9.

72. Fantini J, Di Scala C, Chahinian H, Yahi N. Structural and molecular modelling studies reveal a new mechanism of action of chloroquine and hydroxychloroquine against SARS-CoV-2 infection. Int J Antimicrob Agents. 2020;55(5):105960.

73. Toscano G, Palmerini F, Ravaglia S, Ruiz L, Invernizzi P, Cuzzoni MG, Franciotta D, Baldanti F, Daturi R, Postorino P, Cavallini A, Micieli G. Guillain-Barré syndrome associated with SARS-CoV-2. N Engl J Med. 2020;382(26):2574-6.

74. Graham BS, Sullivan NJ. Emerging viral diseases from a vaccinology perspective: preparing for the next pandemic. Nat Immunol. 2018;19(1):20-8.

75. Krammer F. SARS-CoV-2 vaccines in development. Nature. 2020;586(7830):516-27.

76. Ura T, Yamashita A, Mizuki N, Okuda K, Shimada M. New vaccine production platforms used in developing SARS-CoV-2 vaccine candidates. Vaccine. 2021;39(2):197-201.

77. Pielnaa P, Al-Saadawe M, Saro A, Dama MF, Zhou M, Huang Y, Huang J, Xia Z. Zika virus-spread, epidemiology, genome, transmission cycle, clinical manifestation, associated challenges, vaccine and antiviral drug development. Virology. 2020;543: 34-42.

78. Vannice KS, Cassetti MC, Eisinger RW, Hombach J, Knezevic I, Marston HD, Wilder-Smith A, Cavaleri M, Krause PR. Demonstrating vaccine effectiveness during a waning epidemic: a WHO/NIH meeting 
report on approaches to development and licensure of Zika vaccine candidates. Vaccine. 2019;37(6): 863-8.

79. Polack FP, Thomas SJ, Kitchin N, Absalon J, Gurtman A, Lockhart S, Perez JL, Pérez Marc G, Moreira ED, Zerbini C, Bailey R, Swanson KA, Roychoudhury S, Koury K, Li P, Kalina WV, Cooper D, Frenck RW Jr, Hammitt LL, Türeci Ö, Nell H, Schaefer A, Ünal S, Tresnan DB, Mather S, Dormitzer PR, Şahin U, Jansen KU, Gruber WC, C4591001 Clinical Trial Group. Safety and efficacy of the BNT162b2 mRNA Covid-19 vaccine. N Engl J Med. 2020;383(27): 2603-15.

80. Baden LR, El Sahly HM, Essink B, Kotloff K, Frey S, Novak R, Diemert D, Spector SA, Rouphael N, Creech CB, McGettigan J, Khetan S, Segall N, Solis J, Brosz A, Fierro C, Schwartz H, Neuzil K, Corey L, Gilbert P, Janes H, Follmann D, Marovich M, Mascola J, Polakowski L, Ledgerwood J, Graham BS, Bennett H, Pajon R, Knightly C, Leav B, Deng W, Zhou H, Han S, Ivarsson M, Miller J, Zaks T, COVE Study Group. Efficacy and safety of the mRNA-1273 SARS-CoV-2 vaccine. N Engl J Med. 2021;384(5): 403-16.

81. Toro G, Vergara I, Román G. Neuroparalytic accidents of antirabies vaccination with suckling mouse brain vaccine. Clinical and pathologic study of 21 cases. Arch Neurol. 1977;34(11):694-700.

82. Hemachudha T, Griffin DE, Chen WW, Johnson RT. Immunologic studies of rabies vaccination-induced Guillain-Barré syndrome. Neurology. 1988;38(3): 375-8.

83. Haber P, Sejvar J, Mikaeloff Y, DeStefano F. Vaccines and Guillain-Barré syndrome. Drug Saf. 2009;32(4): 309-23.

84. Tuttle J, Chen RT, Rantala H, Cherry JD, Rhodes PH, Hadler S. The risk of Guillain-Barré syndrome after tetanus-toxoid-containing vaccines in adults and children in the United States. Am J Public Health. 1997;87(12):2045-8.

85. Ismail EA, Shabani IS, Badawi M, Sanaa H, Madi S, Al-Tawari A, Nadi H, Zaki M, Al-saleh Q. An epidemiologic, clinical, and therapeutic study of childhood Guillain-Barré syndrome in Kuwait: is it related to the oral polio vaccine? J Child Neurol. 1998;13(10):488-92.
86. Principi N, Esposito S. Vaccine-preventable diseases, vaccines and Guillain-Barre' syndrome. Vaccine. 2019;37(37):5544-50.

87. Sadoff J, Le Gars M, Shukarev G, Heerwegh D, Truyers C, de Groot AM, Stoop J, Tete S, Van Damme W, Leroux-Roels I, Berghmans PJ, Kimmel M, Van Damme P, de Hoon J, Smith W, Stephenson KE, De Rosa SC, Cohen KW, McElrath MJ, Cormier E, Scheper G, Barouch DH, Hendriks J, Struyf F, Douoguih M, Van Hoof J, Schuitemaker H. Interim results of a phase 1-2a trial of Ad26.COV2.S Covid19 vaccine. N Engl J Med. 2021;384(19):1824-35.

88. Márquez Loza AM, Holroyd KB, Johnson SA, Pilgrim DM, Amato AA. Guillain-Barré syndrome in the placebo and active arms of a COVID-19 vaccine clinical trial: temporal associations do not imply causality. Neurology. (in press).

89. Waheed S, Bayas A, Hindi F, Rizvi Z, Espinosa PS. Neurological complications of COVID-19: GuillainBarre syndrome following Pfizer COVID-19 Vaccine. Cureus. 2021;13(2):e13426.

90. Schonberger LB, Bregman DJ, Sullivan-Bolyai JZ, Keenlyside RA, Ziegler DW, Retailliau HF, Eddins DL, Bryan JA. Guillain-Barre syndrome following vaccination in the National Influenza Immunization Program, United States, 1976-1977. Am J Epidemiol. 1979;110(2):105-23.

91. Langmuir AD, Bregman DJ, Kurland LT, Nathanson $\mathrm{N}$, Victor M. An epidemiologic and clinical evaluation of Guillain-Barré syndrome reported in association with the administration of swine influenza vaccines. Am J Epidemiol. 1984;119(6):841-79.

92. Lehmann HC, Hartung HP, Kieseier BC, Hughes RA. Guillain-Barré syndrome after exposure to influenza virus. Lancet Infect Dis. 2010;10(9):643-51.

93. Kwong JC, Vasa PP, Campitelli MA, Hawken S, Wilson K, Rosella LC, Stukel TA, Crowcroft NS, McGeer AJ, Zinman L, Deeks SL. Risk of GuillainBarré syndrome after seasonal influenza vaccination and influenza health-care encounters: a selfcontrolled study. Lancet Infect Dis. 2013;13(9): 769-76. 